\title{
PELATIHAN PENGGUNAAN PRAKTIKUM VIRTUAL PhET BAGI GURU SD TLOGOSARI WETAN 01 SEMARANG
}

\author{
Iryan Dwi Handayani ${ }^{1)}$, Seno Suharyo'1), Wahjoerini ${ }^{2)}$
}

\author{
1)Program Studi Teknik Sipil, Fakultas Teknik, Universitas Semarang, Semarang, Jawa Tengah, Indonesia \\ 2) Program Studi Perencanaan Wilayah Kota, Fakultas Teknik, Universitas Semarang, Semarang, Jawa Tengah, \\ Indonesia \\ Corresponding author : Iryan Dwi Handayani \\ E-mail : iryandwi1201@gmail.com
}

Diterima 26 Januari 2021, Direvisi 23 Februari 2021, Disetujui 25 Februari 2021

\begin{abstract}
ABSTRAK
Pembelajaran daring sekarang sedang dilaksanakan oleh semua jenjang pendidikan di dunia karena adanya pendemi covid 19. Tenaga pendidik diminta membuat pembelajaran semenarik mungkin walaupun lewat online. DPhet merupakan praktikum simulasi interaktif fenomena Fisika, matematika, biologi dan kimia yang berbasis riset. Tim pengabdian memberikan pelatihan tentang penggunaan $P h E T$ dengan tujuan memberikan alternatif praktikum secara online kepada guru SD Tlogosari Wetan 01. Metode yang digunakan dalam pengabdian ini adalah pelatihan langsung kepada guru dan tenaga kependidikan di lingkungan SD Tlogosari Wetan 01 Semarang tentang penggunaan PhET dalam proses pembelajaran terutama praktikum.
\end{abstract}

Kata kunci: PhET; praktikum simulasi

\begin{abstract}
Online learning is now being carried out by all levels of education in the world because of the Covid 19 epidemic. Educators are asked to make learning as interesting as possible even though it is online. DPhet is a research-based interactive simulation practicum of physics, mathematics, biology and chemistry phenomena. The community service team provides training on the use of PhET with the aim of providing an alternative online practicum for SD Tlogosari Wetan 01 teachers. The method used in this service is direct training for teachers and education personnel in SD Tlogosari Wetan 01 Semarang on the use of $\mathrm{PhET}$ in the learning process, especially practicum.
\end{abstract}

Keywords: PhET; simulation practicum

\section{PENDAHULUAN}

Pelakasanaan pembelajaran secara online ini dilaksanakan sejauh mungkin supaya peserta didik bisa memahami dan mengerti tentang materi yang diajarkan. Pembelajaran sistem online otomatis mendorong pelaku pendidikan untuk melaksanakan pembelajran secara online (Simatupang et al., 2020). Pembelajaran jarak jauh mendorong munculnya perilaku social distancing dan meminimalisir munculnya keramaian sehingga dianggap dapat mengurangi potensi penyebaran covid-19 (Firman \& Rahayu, 2020).

Pemerintah pusat telah menyediakan berbagai macam aplikasi yang bisa digunakan baik oleh siswa ataupun guru secara gratis. Selain itu ada pembelajaran di TVRI yang bisa dilihat siswa di setiap pagi hari, ada juga sebuh aplikasi yang sebenarnya berbayar, tetapi karena pandemi seperti ini dibuka gratis untuk siswa SD sampai SMA.

SD Tlogosari Wetan 01 terletak di Jl. Syuhada Raya N0.14 dan mempunyai jumlah siswa 480 siswa yang terdiri dari kelas I - VI. Masing-masing kelas terbagi menjadi kelas $A$ dan B. Karena setiap guru dan siswa sekarang sudah memiliki laptop ataupun hp yang bisa digunakan untuk melaksanakan pembelaaran secara online, maka untuk melaksanakan pembelajaran online sudah tidak terkendala lagi. Akan tetapi kendalanya adalah pada saaat pembelajaran tersebut tidak interkatif, jadi siswa hanya bisa melihat dan mendengarkan saja tanpa bisa mencobanya. Praktikum IPA, matematika untuk siswa SD Tlogosari Wetan 01 selama masa pandemi masih dengan menggunakan cara hanya membaca buku dan youtube saja.

Dari uraian di atas dapat ditarik permasalahannya adalah guru di SD Tlogosari Wetan 01 belum bisa memberikan pembelajaran praktikum IPA dan matematika yang sifatnya interaktif. Tim PkM dari Universitas Semarang memberikan pelatihan tentang bagaimana memanfaatkan simulasi 
PhET sebagai sarana praktikum di laboratorium secara virtual tetapi interaktif.

Hasil penelitian tentang strategi berpikir hipotetikal deduktif dengan PhET simulations dapat meningkatkan keterampilan berpikir kritis pada pembelajran fisika materi usaha dan energi (Ramadoan et al., 2019). Pengembangan keterampilan berpikir kritis siswa SMA pada topik domain elektron juga mengalami perubahan yang signifikan dengan menggunakan simulasi PhET ini (Stiawan et al., 2014). Praktikum berbantuan PhET ini juga bisa digunakan untuk membantu pembuatan desain riset pembelajaran listrik sehingga dapat melatihkan keterampilan proses siswa (Keterampilan \& Sains, 2017)

Pengembangan E-Learning fisika menggunakan Phet pada materi pokok dinamika gerak lurus juga dapat meningkatkan keterampilan berfikir kritis siswa jika dilihat dari beberapa aspek (Zainudin, 2017). Praktikum fisika dapat meningkatkan aspek berpikir, akan tetapi ada beberapa hal yang dapat menyebabkan praktikum tidak optimal antara lain petunjuk praktikum pada umumnya bersifat resep yang berisi langkah-langkah yang harus dilakukan, peralatan yang kurang memadai dan kegiatan praktikum memerlukan waktu yang lama sehingga memerlukan pengaturan jadwal (Keterampilan \& Sains, 2017)

Karakteristik laboratorium virtual adalah program yang berisi alat-alat laboratorium yang berfungsi sebagaimana alat riil. Para siswa diajak untuk memberikan respon yang ada pada laboratorium virtual, kemudian komputer akan merespon dan memberikan umpan balik segera pada pengguna dalam bentuk program instruction (Hamida et al., 2013).

Penggunaan laboratorium virtual lebih efektif dibandingkan dengan penggunaan praktikum riil, dilihat dari hasil belajar peserta didik SMA Rahmatul Asri Enrekang (Kadir \& Keguruan, 2014). Format tampilan laboratorium virtual berbasis web bisa membantu mahasiswa dalam melakukan praktikum secara mandiri. Virtual Laboratory dikategorikan menjadi 5 (Gunawan et al., 2017), yaitu:

1. Simulasi klasik yang berisi unsur-unsur percobaan laboratorium tertentu dan tersedia di tempat itu (simulation).

2. Simulasi klasik yang berisi unsur-unsur percobaan laboratorium tertentu dan dapat diakses secara online (cyber laboratory).

3. Simulasi yang mencoba menghadirkan percobaan laboratorium yang sedapat mungkin sesuai dengan eksperimen sesungguhnya (virtual lab).

4. Simulasi laboratorium yang mengadakan percobaan menggunakan virtual reality techniques (VR lab).
5. Eksperimen riil yang dikendalikan via jaringan atau internet (internet lab).

PhET merupakan simulasi interaktif fenomena-fenomena fisis, berbasis riset yang diberikan secara gratis. PhET adalah simulasi ilmu fisika, kimia, biologi ilmu bumi dan matematika. Situs ini menyediakan simulasi pembelajaran yang gratis untuk didownload dalam kepentingan pembelajaran di kelas ataupun belajar mandiri. PhET merupakan software pembelajaran dari Universitas Colorado. Simulasi yang disediakan sangat interaktif yang mengajak pembelajar untuk mengeksplorasi secara langsung. Alat ukur juga disediakn dalam simulasi ini, seperti penggaris, stopwatch, voltmeter dan termometer. Simulasi PhET ini selain bisa digunakan secar online, bisa juga digunakan offline. Dengan syarat komputer mempunyai program Java dan Flash. Sehingga tujuan dari pelaksanaan kegiatan pengabdian kepada masyarakat ini adalah untuk memberikan pelatihan tentang penggunaan PhET, sehingga para guru dan tenaga kependidikan bisa mengaplikasikan dalam proses belajar mengajar. Dengan pembelajaran daring seperti ini, ditemukan kenyamanan dalam mengemukakan gagasan dan pertanyaan dalam pembelajaran daring (Sadikin \& Hamidah, 2020).

\section{METODE}

Metode pelaksanaan pelatihan penggunaan PhET dilakukan dengan cara pelatihan atau workshop. Dilakukan di SD Tlogosari Wetan 01 Semarang dengan diiukuti oleh 12 guru kelas dan 8 tenaga kependidikan. Tahapan yang dilakukan oleh tim PkM dalam kegiatan pelatihan penggunaan PhET adalah sebagai berikut:

1. Tahap Identifikasi Permasalahan.

Pada tahapan ini diawali dengan survei dan wawancara dengan kepala sekolah tentang pelatihan yang akan dilaksanakan untuk guru dan seluruh tenaga kependidikan di SD Tlogosari wetan 01, kemudian menentukan waktu dan tempat pelaksanaan pelatihan.

2. Tahap pendekatan penyelesaian masalah. Pelaksanaan pelatihan praktikum simulasi dengan menggunakan PhET ini diawali dengan pemberian informasi tentang apa itu PhET dan fungsinya untuk apa saja. Dibagikan modul untuk bisa menggunakan simulasi PhET. Selanjutnya adalah melaksanakan kegiatan pelatihan dengan bapak ibu guru SD Tlogosari Wetan 01. Karena situasi dan kondisi yang tidak 
memungkinkan untuk melaksanakan dengan berkumpul orang banyak, maka kita melaksanakan dengan beberapa tahapan.

Tahapan yang pertama adalah dengan memberikan materi yang berupa hard copy isinya tentang pengertian Phet, fungsinya dan bagian-bagian yang bisa kita gunakan di PhET. Kemudian untuk selanjutnya adalah melaksanakan pelatihan yang dilaksanakan terpisah, yang pertama adalah untuk guru kelas VI.

3. Tahap Evaluasi

Dalama tahapan ini dituliskan tentang dokumentasi pengabdian, hasil yang diperoleh selama pelatihan berlangsung dan luaran yang dihasilkan.

\section{HASIL DAN PEMBAHASAN}

Hasil dari identifikasi permasalahan didapatkan bahwa guru di SD Tlogosari Wetan 01 belum bisa menggunakan simulasi praktikum secara online, maka tim pengabdian akan memberikan pelatihan kepada guru dan tenaga kependidikan di SD Tlogosari Wetan 01 Semarang.

Kegiatan pelatihan praktikum simulasi dengan menggunakan PhET ini diawali dengan pemberian informasi tentang apa itu PhET dan fungsinya untuk apa saja. Dibagikan modul untuk bisa menggunakan simulasi PhET. Selanjutnya melaksanakan kegiatan pelatihan dengan bapak ibu guru SD Tlogosari Wetan 01. Karena situasi dan kondisi yang tidak memungkinkan untuk melaksanakan dengan berkumpul orang banyak, maka kita melaksanakan dengan cara bertahap.

Tahapan yang pertama adalah dengan memberikan materi yang berupa hard copy isinya tentang pengertian Phet, fungsinya dan bagian-bagian yang bisa kita gunakan di PhET. Kemudian untuk selanjutnya adalah melaksanakan pelatihan yang dilaksanakan terpisah, yang pertama adalah untuk guru kelas VI. Pelatihan dimulai dengan cara membuka PhET, ini sangat mudah karena tidak harus mendownload di appstore atau play store. Setelah itu kita bisa memilih gradenya sesuai yang diinginkan. Seperti gambar 1.

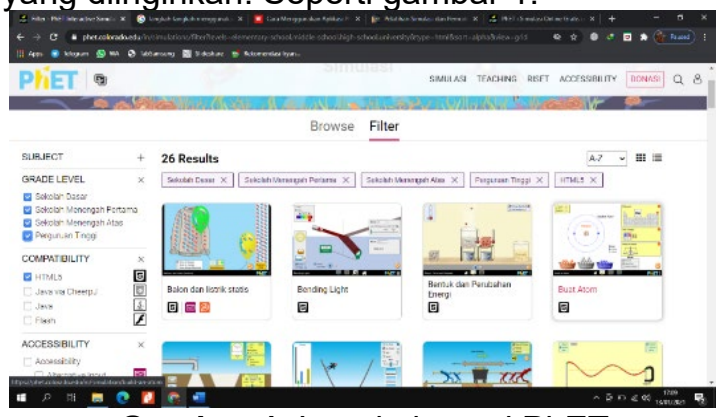

Gambar 1. Langkah awal PhET
Karena sasaran pelatihan adalah guru SD, maka mereka memilih grade Sekolah Dasar. Grade level yang disediakan mulai dari Sekolah Dasar, Sekolah Menengah Pertama, Sekolah Menengah Atas dan Perguruan Tinggi. Kemudian setelah memilih grade, langkah selanjutnya adalah memilih berbagai macam praktikum yang bisa disimulasikan di PhET. Salah satu contohnya adalah bentuk dan perubahan energi, seperti gambar 2 .

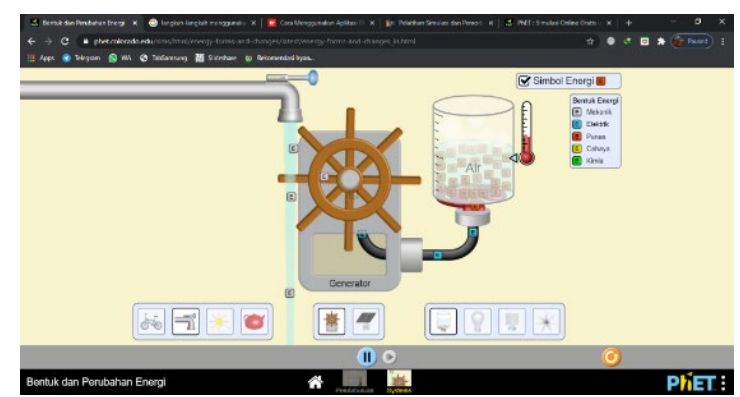

Gambar 2. Praktikum Bentuk dan PerubahanEnergi

Hasil yang diperoleh dari pelatihan yang dilakukan adalah para guru sangat antusias dalam menggunakan PhET dalam pembelajaran, terutama pembelajaran matematika, fisika dan biologi. Karena dalam situasi pandemi seperti ini yang dituntut semua pembelajaran dilaksanakan secara daring, dengan simulasi PhET ini sangat membantu. Seperti yang terlihat pada gambar 3 , pelatihan untuk guru kelas VI.

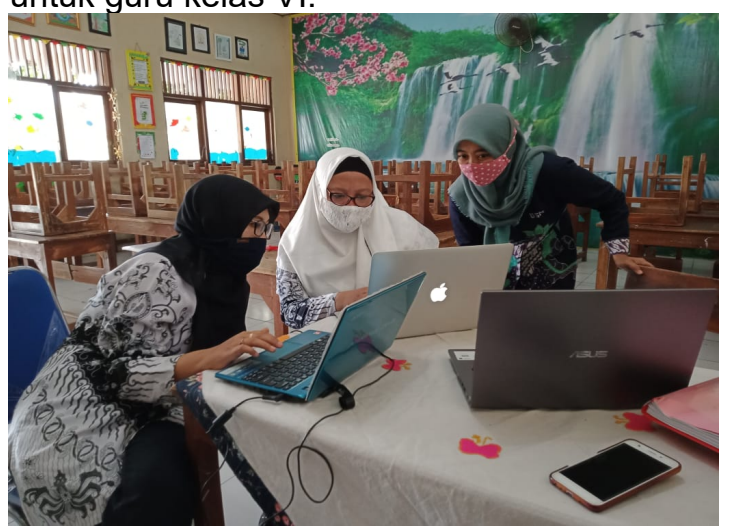

Gambar 3. Pelatihan PhET untuk guru kelas VI

\section{SIMPULAN DAN SARAN}

Kegiatan pelatihan praktikum simulasi dengan menggunakan PhET berjalan dengan baik. Terbukti dengan pelaksanaan pelatihan yang berlangsung sangat lancar dan tiap-tiap guru langsung menerapkan dalam proses belajar mengajar di dalam kelas walaupun secara online. Penggunaan Phet ini sangat disarankan untuk menjelaskan beberapa praktikum baik matematika, fisika atau biologi yang dilaksanakan secara online. 


\section{UCAPAN TERIMAKASIH}

Penulis mengucapkan terimaksih kepada Universitas Semarang dan LPPM Universitas Semarang, yang telah memfasilitasi kegiatan pengabdian kepada masyarakat ini dapat terealisasi.

\section{DAFTAR RUJUKAN}

Firman, F., \& Rahayu, S. (2020). Pembelajaran Online di Tengah Pandemi Covid-19. Indonesian Journal of Educational Science (IJES), 2(2), 81-89. https://doi.org/10.31605/ijes.v2i2.659

Gunawan, G., Harjono, A., \& Sahidu, H. (2017). Studi Pendahuluan Pada Upaya Pengembangan Laboratorium Virtual bagi Calon Guru Fisika. Jurnal Pendidikan Fisika Dan Teknologi, 1(2), 140. https://doi.org/10.29303/jpft.v1i2.250

Hamida, N., Mulyani, B., \& Utami, B. (2013). Studi Komparasi Penggunaan Laboratorium Virtual Dan Laboratorium Riil Dalam Pembelajaran Student Teams Achievement Division (Stad) Terhadap Prestasi Belajar Ditinjau Dari Kreativitas Siswa. Jurnal Pendidikan Kimia Universitas Sebelas Maret, 2(2), 7-15.

Kadir, A. R., \& Keguruan, F. T. (2014). Laboratorium Riil Dengan Laboratorium Virtual.

Keterampilan, M., \& Sains, P. (2017). DESAIN RISET PERANGKAT PEMBELAJARAN MENGGUNAKAN MEDIA KIT LISTRIK YANG DILENGKAPI PhET BERBASIS INKUIRI UNTUK MELATIHKAN KETERAMPILAN PROSES SAINS. USEJ: Unnes Science Education Journal, 5(3), 1331-1342. https://doi.org/10.15294/usej.v5i3.13162

Ramadoan, N., Suisworo, D., \& Jauhari, I. (2019). Strategi Berpikir Hipotetikal Deduktif Dengan Phet Simulations Terhadap Keterampilan Berpikir Kritis Pada Pembelajaran Fisika Materi Usaha Dan Energi Kelas X Sma. Prosiding SNFA (Seminar Nasional Fisika Dan Aplikasinya), 306. https://doi.org/10.20961/prosidingsnfa.v3i 0.28548

Sadikin, A., \& Hamidah, A. (2020). Pembelajaran Daring di Tengah Wabah Covid-19. Biodik, 6(2), 109-119. https://doi.org/10.22437/bio.v6i2.9759

Simatupang, N., Sitohang, S., Situmorang, A., \& Simatupang, I. (2020). Efektivitas Pelaksanaan Pengajaran Online Pada Masa Pandemi Covid-19 Dengan Metode Survey Sederhana. Jurnal Dinamika Pendidikan, 13(2), 197-203. https://doi.org/10.33541/jdp.v13i2.1754

Stiawan, E., Liliasari, L., \& Rohman, I. (2014). PENGEMBANGAN KETERAMPILAN BERPIKIR KRITIS SISWA SMA PADA TOPIK TEORI DOMAIN ELEKTRON MELALUI SIMULASI INTERAKTIF PhET MOLECULE SHAPES. Jurnal Pengajaran Matematika Dan Ilmu Pengetahuan Alam, 19(2), 257. https://doi.org/10.18269/jpmipa.v19i2.468

Zainudin, Z. (2017). Pengembangan ELearning Fisika Menggunakan Phet (Physics Educational Technology) Pada Materi Pokok Dinamika Gerak Lurus Berbasis Keterampilan Berfikir Kritis. Jurnal Pena Sains, 4(1), 22. https://doi.org/10.21107/jps.v4i1.2777 